\title{
Deutiche Bedenftage
}

\author{
Reden
}

voll

\section{9rof. Dr. Chr. Cofert \\ (Sebeimer Regierungitat

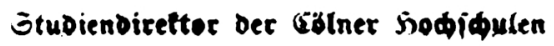

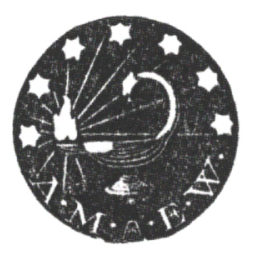

BoIII 1S15

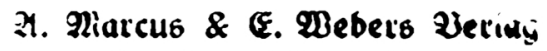

(Dr. jur. albert abn)

(6) 


\section{Radbruat perboten.}

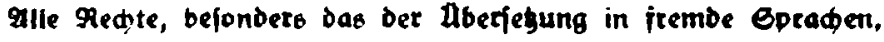
vorbebalten.

Copyright by A. Marcus \& E. Webers Verlag (Dr jar. Albest Aha. in Bonn 1918 .

Ф. Pà'lde badbs. Ilypert a Co. 6. m. b. G., Raumburg a. b. 5. 